\title{
Research Paper \\ The Effectiveness of Mind Theory Training based on the Hall and Tager-Flusberg Model and Role Playing on Improving the Theory of Mind in Children with Autism Spectrum Disorder
}

\author{
Fereshteh Yaghooti ${ }^{1}$, Sogand Ghasemzadeh ${ }^{* 2}$, Zahra Ahmadi ${ }^{3}$ \\ 1. Ph.D. in Psychology and Education of Exceptional Children, Science and Research Branch, Islamic Azad University, Tehran, Iran \\ 2. Assistant Professor, Department of Psychology and Education of Exceptional Children, University of Tehran, Iran \\ 3. M.A. Student in Psychology and Education of Exceptional Children, Department of Psychology, Allameh Tabataba'i University, \\ Tehran, Iran
}

Citation: Yaghooti F, Ghasemzadeh S, Ahmadi Z. The effectiveness of mind theory training based on the hall and tager-flusberg model and role playing on improving the theory of mind in children with autism spectrum disorder. Quarterly Journal of Child Mental Health. 2019; 6(3): 295-306.

http://dx.doi.org/10.29252/jcmh.6.3.25

\section{A R T I C L E I N F O}

Keywords:

Autism spectrum

disorder,

theory of Mind,

levels of theory of mind

Received: 26 Oct 2017

Accepted: 21 Sep 2019

Available: 16 Nov 2019

\section{A B S T R A C T}

Background and Purpose: Children with autism spectrum disorder are not only unable to understand the minds of others, but also have underlying problems in understanding that others may have different minds. The purpose of this study was to determine the effectiveness of mind theory training on promoting theory of mind in children with autism. Method: This study was an experimental study with a pretest-posttest design with a control group. 12 children with autism spectrum disorder (age range 7 to 10 years) were selected using convenience sampling and were randomly divided into experimental and control groups. The theory of mind was taught to the experimental group for 25 sessions and the control group did not receive the training. At the end both groups were evaluated in post-test. The research instrument consisted of theory of mind test (Steirnman, 1999, Iranian standard form,2006). The data were analyzed using covariance analysis.

Results: The results of the data analysis showed that the intervention program was able to increase the mean of the subscales of theory of mind in the experimental group ( $\mathrm{p}<0.001)$, while the Post-test scores of the control group in all subscales did not change significantly.

Conclusion: The findings of the present study showed that training the theory of mind increase the ability to recognize and represent emotions (first level of theory of mind), understanding of primary false belief (second level of theory of mind), and an understanding of secondary false belief (third level of theory of mind) in children with autism. The implications of the results are discussed in the paper.

\footnotetext{
* Corresponding author: Sogand Ghasemzadeh, Assistant Professor, Department of Psychology and Education of Exceptional Children, University of Tehran, Iran.

E-mail addresses: S.ghasemzadeh@ut.ac.ir
} 


\section{اثر بخشى آموزش نظريه ذهن بر اساس الكوى هال و تاكر -فلاسبر كى و ايفاى نقش بر بهبود سطوح نظريه ذهن

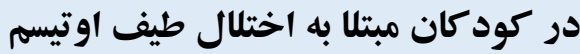

\section{فرشته ياقوتى'، سو كند قاسم زاده"'، زهر ا احمدى"}

ا. دكتراى روانشناسى و آموزش كود كان استثنايى، واحد علوم و تحقيقات، دانشكاه آزاد اسلامى، تهران، ايران

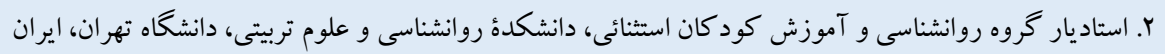

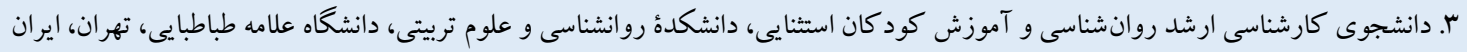

\begin{tabular}{|c|c|}
\hline جكيده & 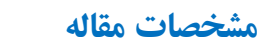 \\
\hline زمينه و هدف: كود كان مبتلا به اختلال طيف او تيسم نه تنها قادر به دركك ذهن ديخر ان نيستند، بلكه در درك اين كه ديخر ان ممكن ذهن & 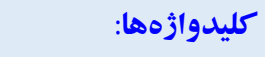 \\
\hline متفاو تى داشته باشند نيز داراى مشكلات اساسى هستند. هدف از اين مطالعه تعيين اثر بخشى آموزش نظريه ذهن بر ارتقاء سطوح نظريه ذهن & 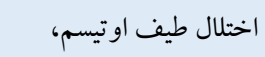 \\
\hline 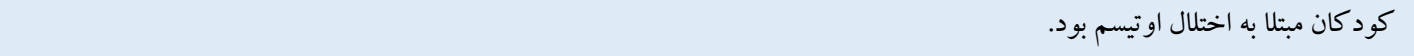 & 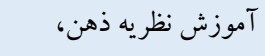 \\
\hline روش: اين يثوهش از نوع مطالعات تجربى با طرح ييش آزمون - يّ آزمون با يك گروه كو اه بود. rا نفر از كود كان مبتلا به اختلال طيف & سطوح نظريه ذهن \\
\hline او تيسم با دامنه سـى V تا •ا سال با استفاده از روش نمونه كيرى در دسترس انتخاب شده و در دو گروه آزمايش و گو اه به صورت تصادفى & \\
\hline جايدهى شـــند. برناهه مداخلهاى نظريه ذهن به مدت هـ جلسـهـ به كروه آزمايش آموزش داده شــــ و گروه كواه اين آموزش را دريافت & \\
\hline 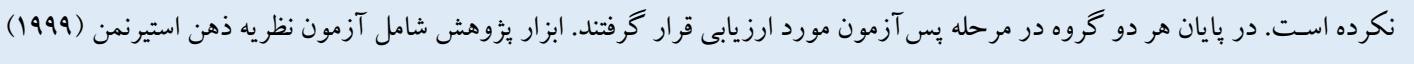 & \\
\hline - فرم ^ץ سوالى با هنجار ايرانى بود. دادههاى به دست آمده با استفاده از تحليل كوواريانس مورد بررسى قرار گرفتند. & \\
\hline 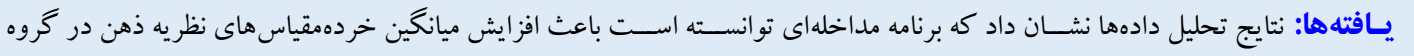 & \\
\hline 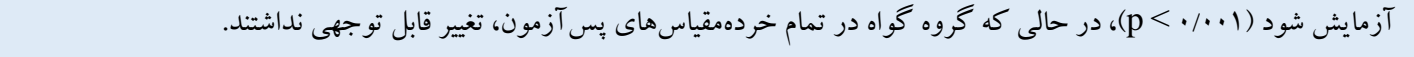 & \\
\hline نتيجه كيرى: يافتههاى يُزوهش حاضـر نشـان داد كه آموزش نظريه ذهن، توانايى بازشـاسى عواطف و وانمودسـازى (سـطح يكك نظريه & 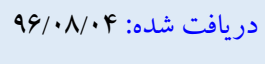 \\
\hline ذهن)، دركك باور غلط اوليه (سـطح دوم نظريه ذهن)، و در كك باور غلط ثانويه (سـطح سـوم نظريه ذهن) كود كان مبتلا به اختلال اوتيسـم را & 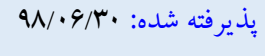 \\
\hline افزايش مى دهد. استلز امهاى نتايج بهدست آمده در مقاله مورد بحث قرار گرفته است. & 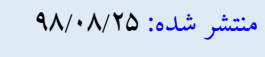 \\
\hline
\end{tabular}

* نويسنده مسئول: سو كند قاسم زاده، استاديار گروه روانشناسى و آموزش كود كان استثائى، دانشكدة روانشناسى و علوم تربيتى، دانشكاه تهران، ايران.

رايانامه: S.ghasemzadeh@ut.ac.ir

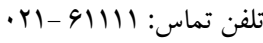


كود كان از حدود ب سـالكى قادر به فهم تمايلات و عو اطف ساده در

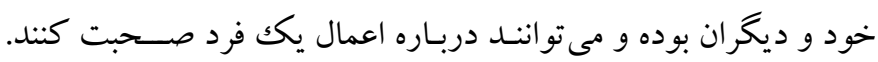

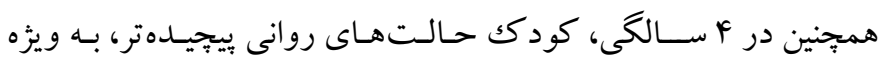
بـاورهـايى را متوجـه مى شــود كـه ممكن اســت در تعـارض بـ با واقعيت

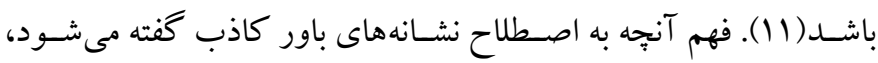

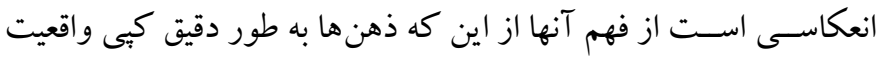
نيست، اما بازنمايىهايى است كه ممكن است درست يا غلط باشد (Y) (I).

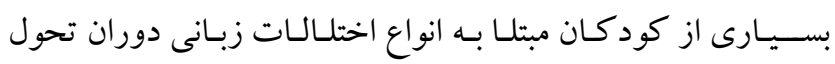
(كود كان با اختلالات فراكير تحولى، كود كان ناشنوا، و كود كان كمتوان

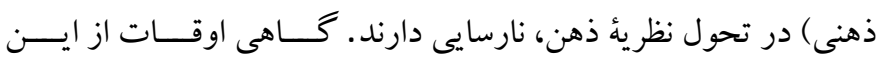

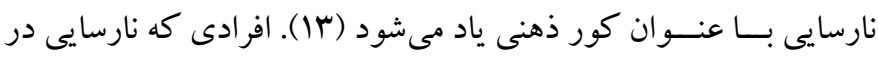

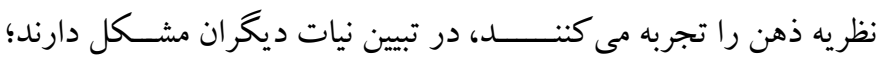

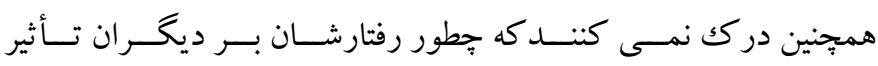

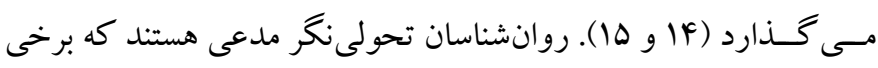
از افراد مبتلا به اختلال طيف او تيسم با وجود استفاده از زبان، قادر به تعبير

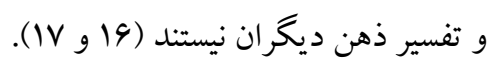

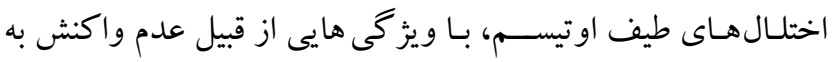

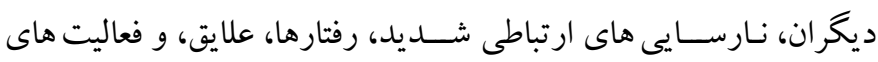

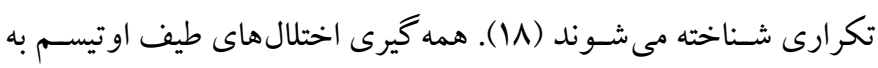

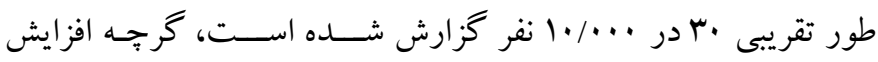

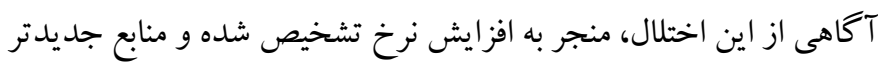

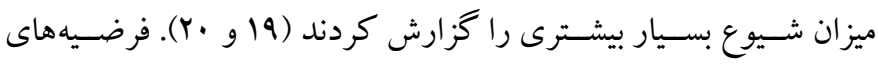

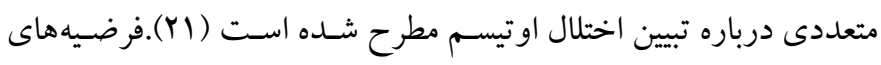
جديد سـببشـناسى، اختلال طيف اوتيسم را به نارسايى در نظريه ذهن و و

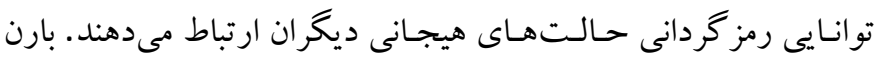

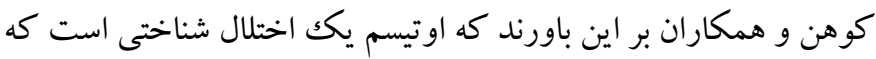
عملكرد اجتماعى را تحت تأثير قرار مىدهد(Yr). به نظر آنها، اين اختلال

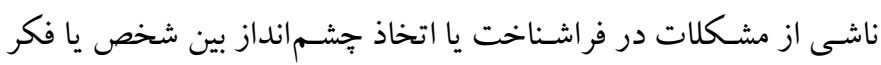

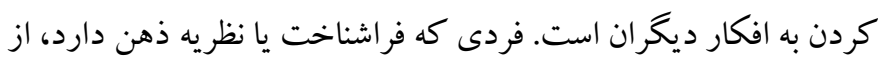

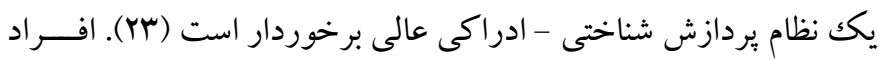

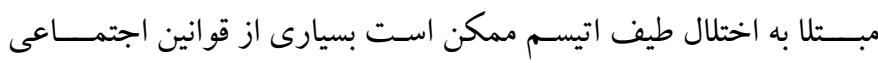

2. Theory of mind
مقلمها

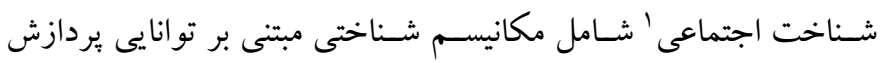
دنياى اجتماعى اسـت كه در دوران كودكى با تحول نظريه ذهن ظهور

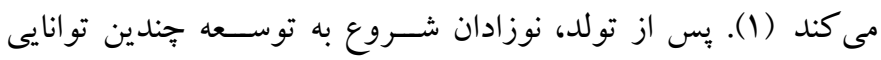

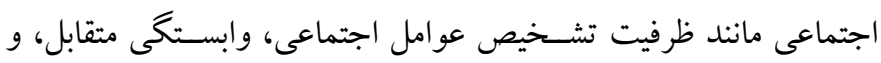
ترجيح الكوهاى اجتماعى نسبت به الكوهاى غير اجتماعى مى كنند (Y).

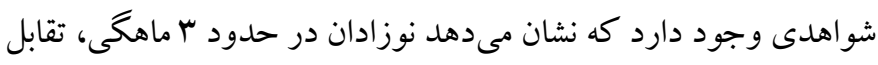
اجتماعى رادر رابطه با تشـخيص احتمالى بين خود (به عنوان مثال بدن

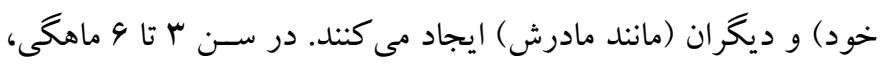

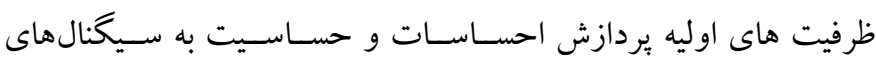

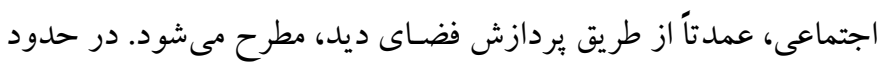

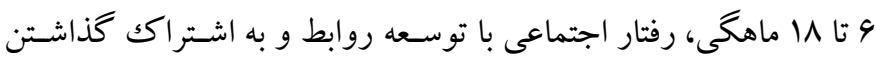

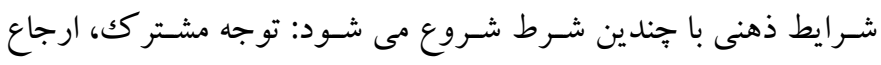

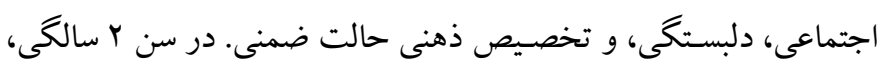

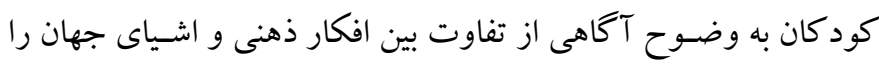

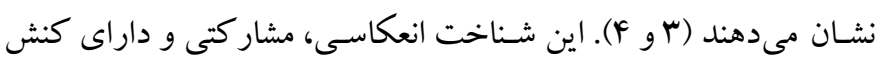

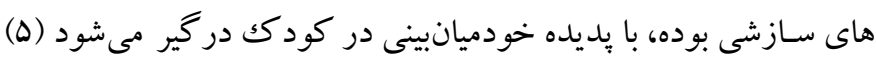

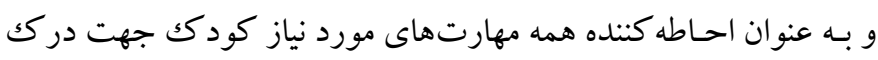

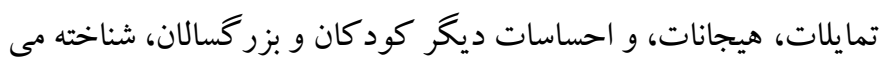

شود (9).

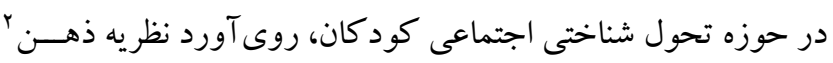

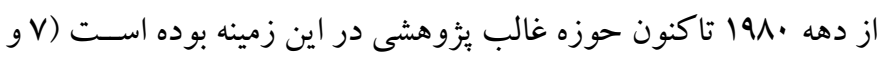

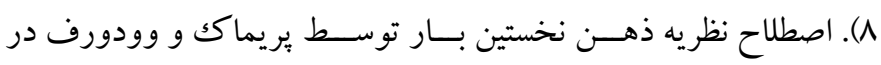

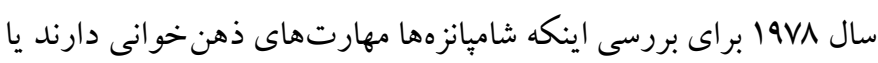

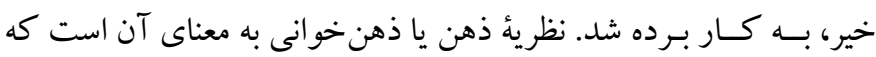

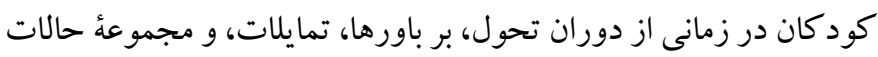

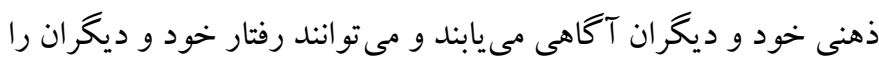

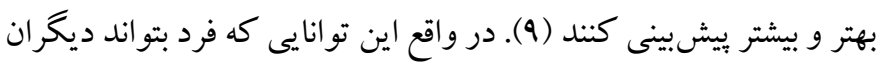

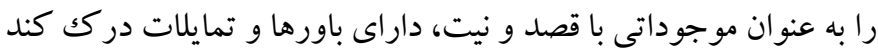

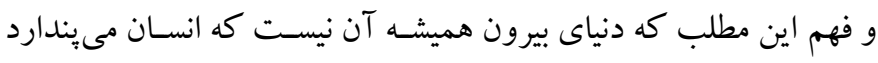

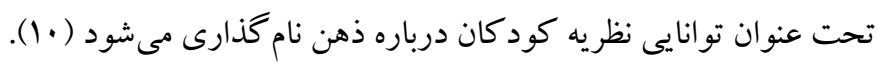

1. Social cognitive 
(r·) نشــان دادنــ كه آموزش باور، ادراكك و ميل باعث بهبود عملكرد

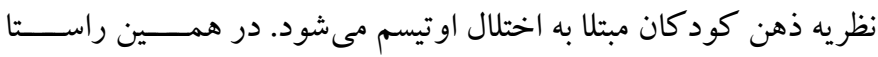

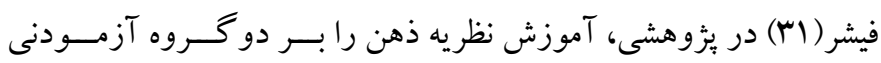

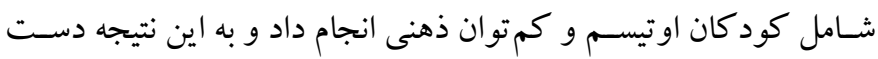

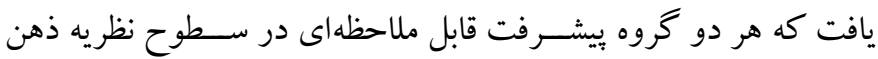

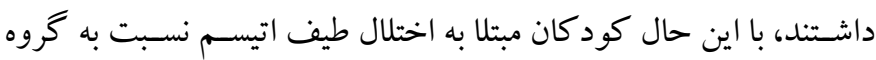
كمتوان ذهنى در در كك افكار و احسـاسـات شـخصـيتهاى داسـتان،

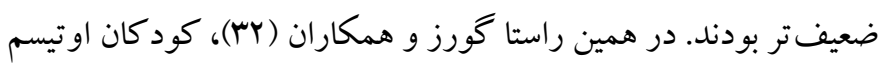

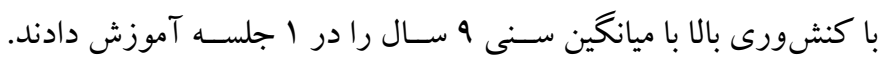

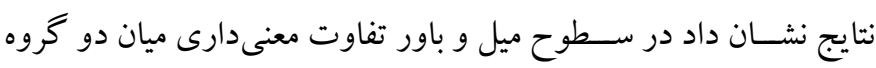
آزمـايش و گَواه يس از آموزش وجود دارد، در حسالى كـه تفــاوت

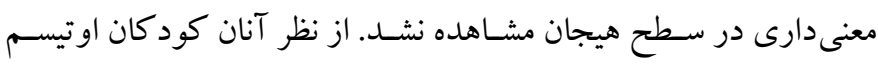

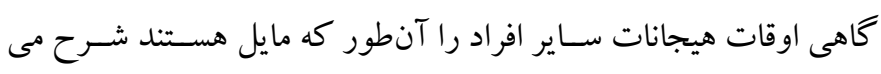
دهند و به ندرت اعتقادات آنها با هيجانـات و اقعى منطبق است. بيخام و همكاران (سش) در مطالعهاى دو گروه كود كان مبتلا به اختلال

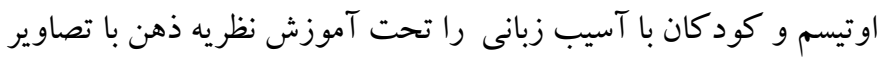
و داستان گويى قرار دادند. هر دو گروه در توصيف و شرح داستانها، از

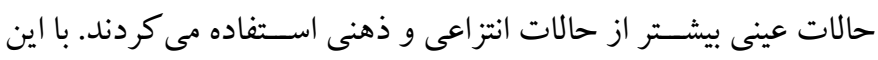

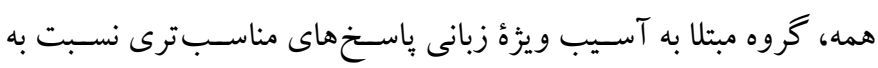

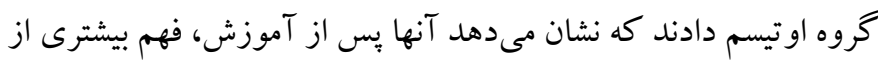

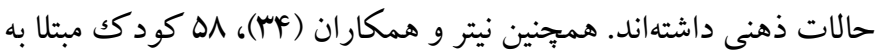

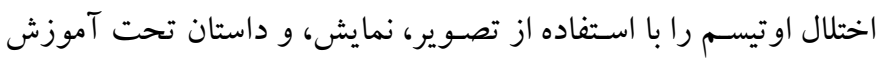

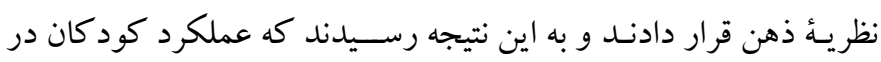

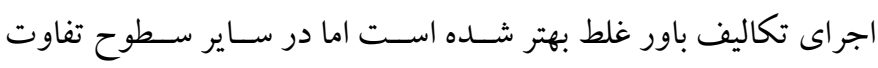
معنى دارى پِ از آموزش مشاهده نكردند.

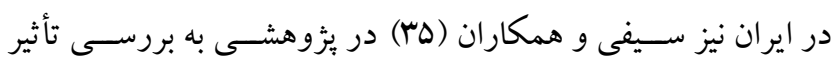

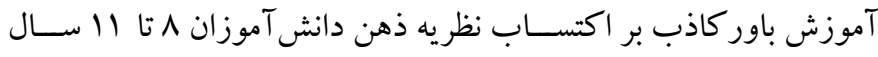

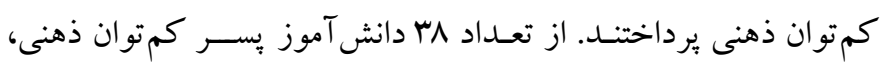

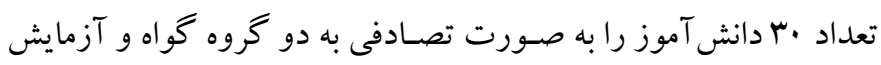

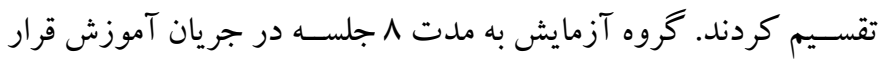

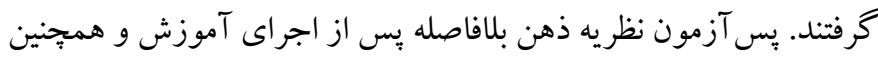

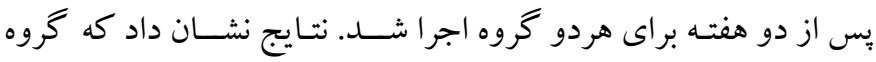

نوشـته نشده را در كك نكنند. زاتمارى (Trץ) بيـان كرد كـه افر اد مبتلا به

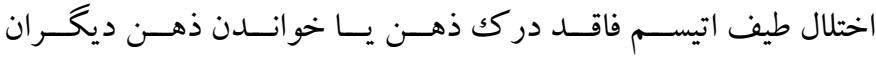

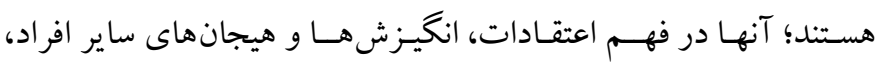

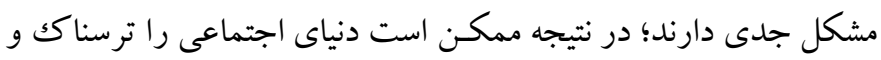

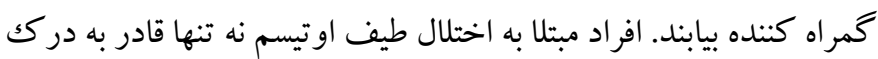

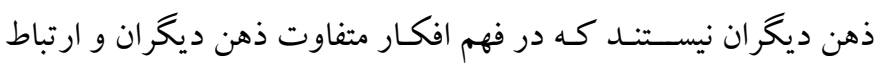
رفتار با حالتهاى روانى ناتوان هستـند (YF). برخى از يزٔوهش ها اشـاره

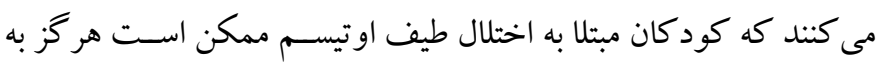

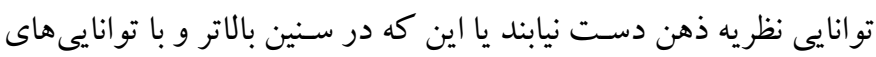

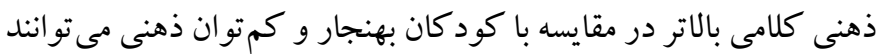
توانايى نظريه ذهن را كسب كنند. بارن كوهن(YO) در بثزوهشـى نشـان داد كـه كود كان مبتلا به اختلال

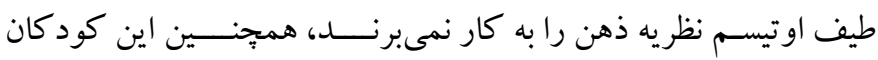

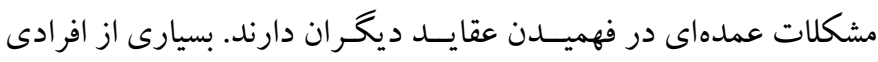

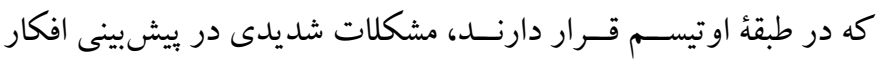

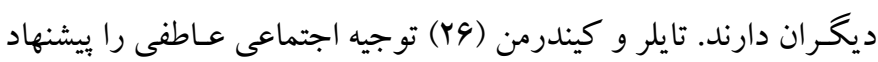
كردند كه نشان مىدهد نارسايى در نظريه ذهن در افــــر اد مبتلا به اختلال

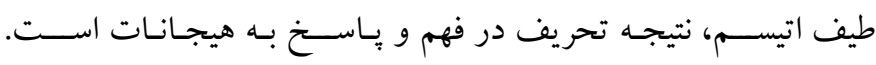

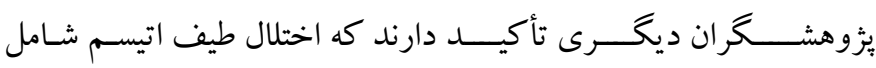

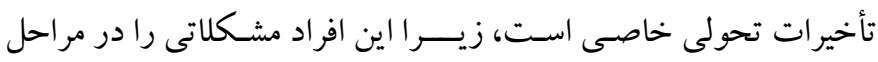
مختلف تحول تجربه مى كنند. بارون كوهن (YN) نشان دادند كه مشكلات

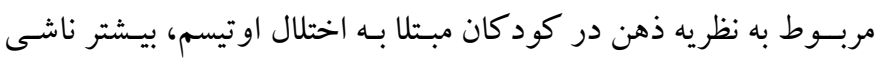

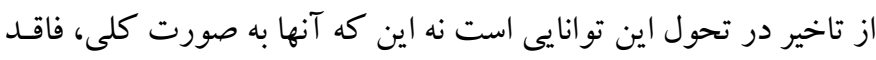

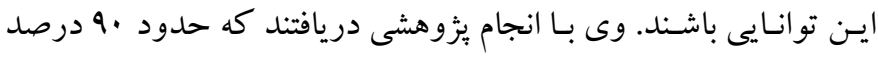

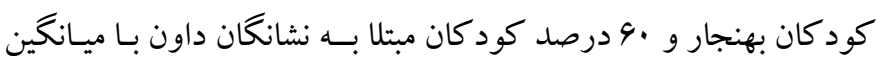
سن هوش كلامى V/ه سال، داراى نظريه ذهن سطح بالاتر بودند، اما هيج

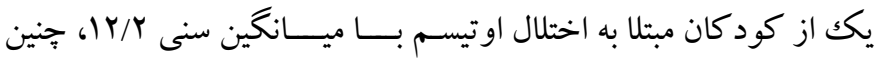

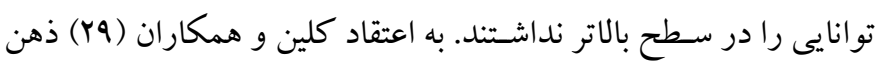

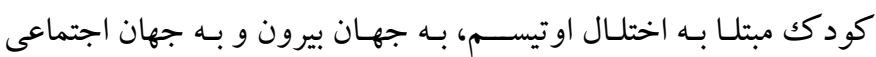
تـوجهى نـدارد. تلاش هايى جهت آموزش نظريه ذهن به كود كان اوتيسـم انجام شـــه اســت. در يكى از اولين كـارهـاى آموزش نظريه ذهن، آلن و همكاران 
بالا از مقياس سـنجش دامنه اوتيسـم' (צY) اسـتفاده و كود كانى كه نمره كلى آنها Y Y بود، به صـورت نمونه در دسترس انتخاب شدند. در نهايت

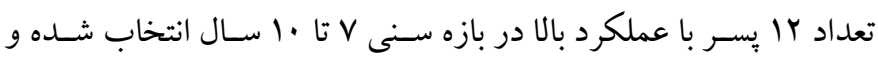

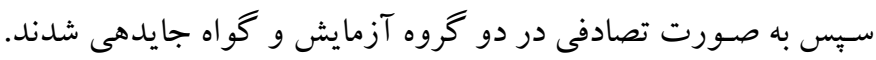

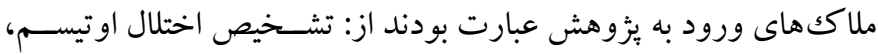

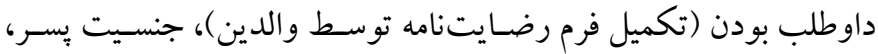

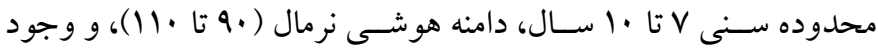

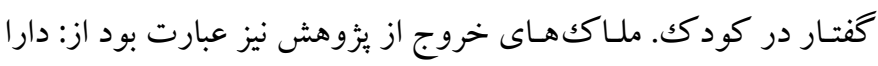

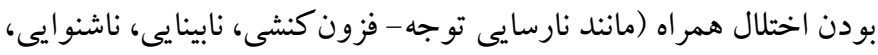

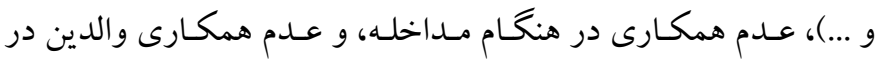

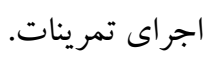
ب) (بزابزار آزمون نظريه ذهن فرم بـ سوالى: فــرم اصسلى ايسـن آزمون، داراى V^

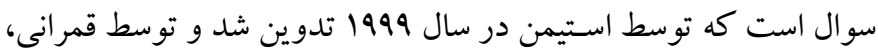

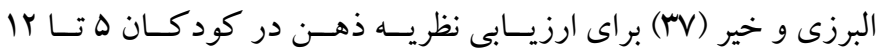

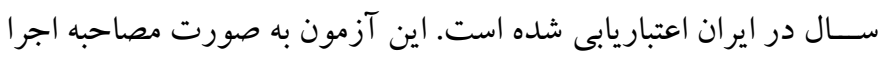

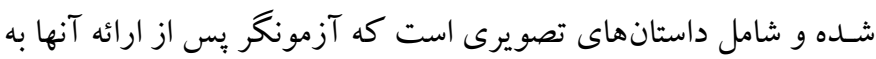

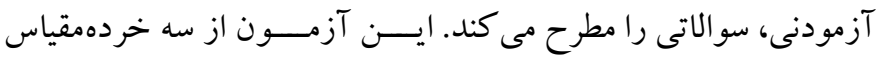

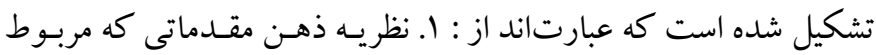
بــه بازشناسى عو اطف و وانمود ســازى اسـت؛ ب. نمـود اوليـه از نظريه

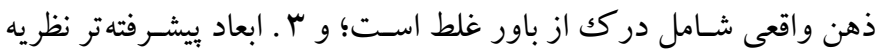

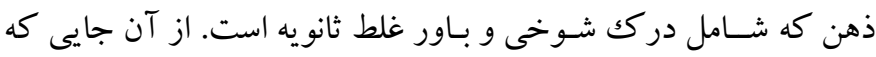

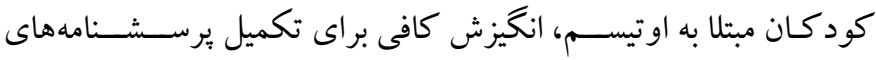

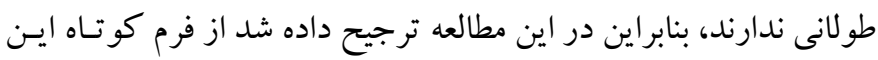

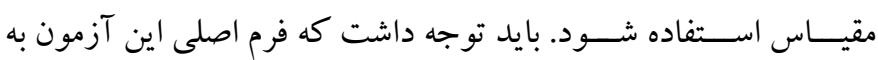

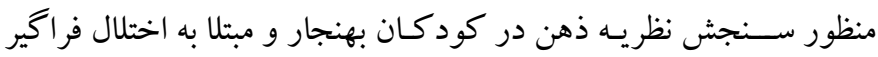
تحولى با ســين ه تا r ا ســال به كار مىرود و اطلاعاتى درباره گســتره درك اجتماعى، حسـاسيت و بينش كودك،، و همجنين ميزان و درجهاى كه وى قادر اسـت احساسات و افكار ديخران را بيذيرد، فر اهم مى آورد.

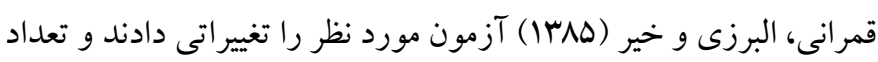

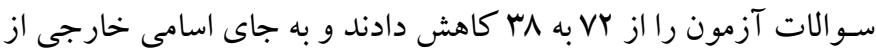

آزمايش نسـبت به گروه گواه عملكرد بهترى در بس آزمون نظريه ذهن

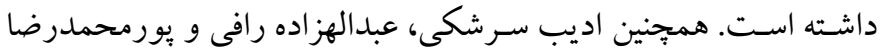

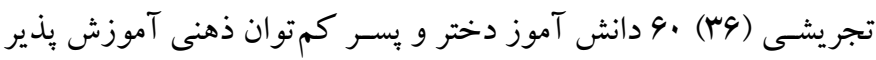

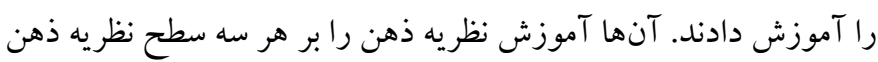

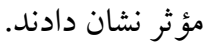
بـا آموزش نظريـه ذهن مى توان به كود كان با اختلال طيف اوتيســم

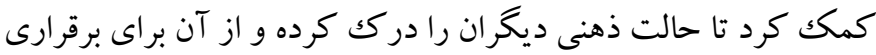

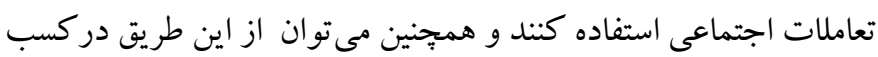

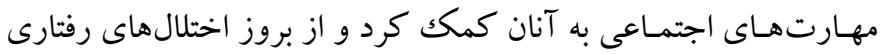
كه به دليل كمبود مهارت در برقرارى تعاملات اجتماعى به وجود مى آيد،

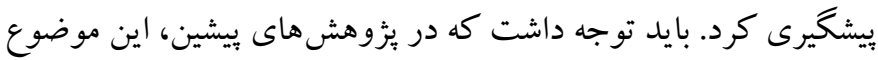

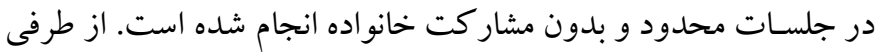

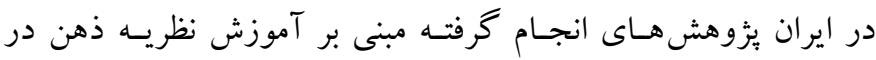

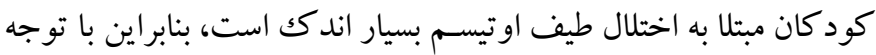

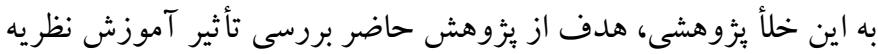

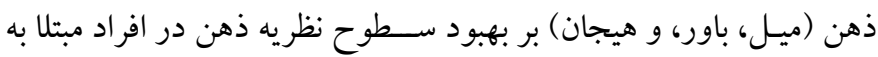

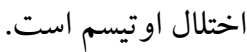

روش

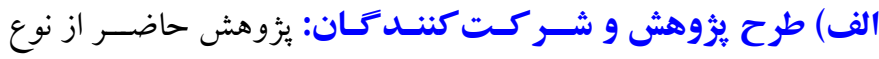
آزمايشى ( بيش آزمون و بس آزمون با گروه گواه) است. جامعه آمارى آن را تمام كود كان مراجعه كننده به مراكز درمانى و آموزشى شهر تبو تبريز

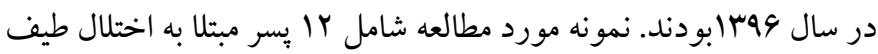

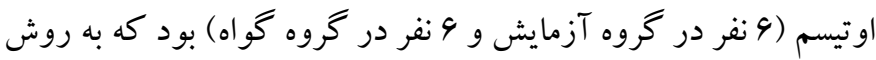
نمونه گيرى در دسـترس انتخاب شـدند. بدين صسورت كه ابتدا فراخوان شـركت در طرح آموزشى منتشـر شــــ و داوطلبين براى شـر كت در اين

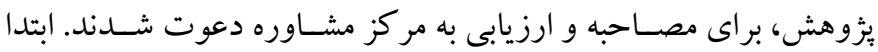

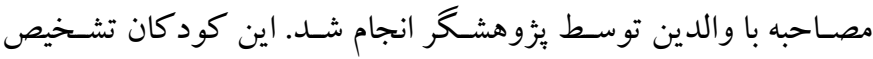

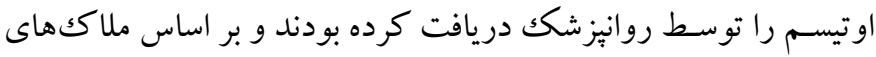

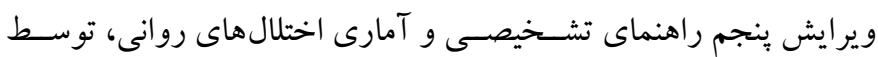
يُزوهشكر نيز ارزيابى شدند. به منظور تفكيك كود كان اوتيسم بأ عملكرد 
ج) برنامه مداخلهاى :برنامه مداخله بر اساس الكوى :ثزوهشى ميلندا

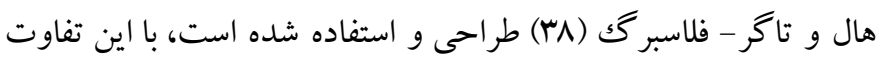

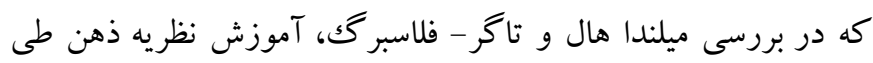
جهار جلسه و در اين يزوهش طى ه广 جلسه انجام شده است و بازى نقش نيز به آن اضافه شده است. اين برنامه شامل الف) آموزش هيجانات با

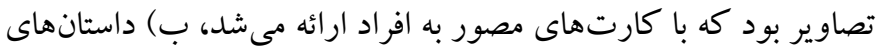
كو تاه كه به صورت لوحه و تصويرسازى شده آماده شده و همراه با تمرين و يرسش و ياسخ كلامى بود، و ج) ايفاى نقش داستانهاى مرحله قبل.

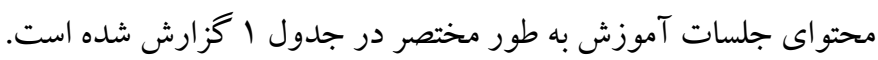

اسـامى فارسـى اسـتفاده كردند. ســـ بر روى تعدادى از دانش آموزان

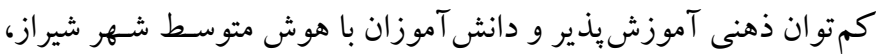

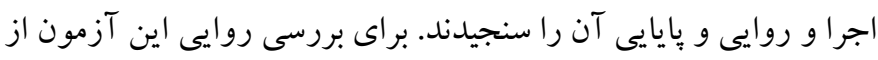

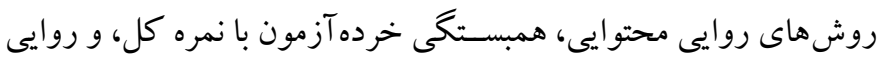
همزمان اسـتفاده شــده اسـت. ضــرايب روايى اين آزمون براى كود كان

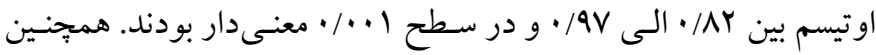

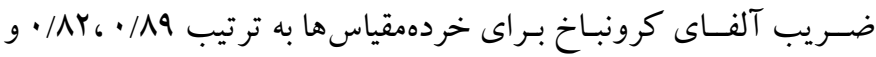

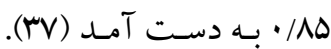

جدول ا: جلسات آموزش نظريه ى ذهن بر اساس الكوى هال و تاكر - فلاسبر كى

شرح فعاليت

ايجاد ارتباط با كودكان شر كت كنده، ايجاد ارتباط با والدين، آشنايى و شرح كلى فرايند آموزش، توضيح درباره نظريه ذهن، بيان اهداف آموزشى، شرح كلى

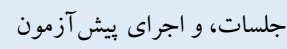

مرورى بر موضوعات جلسات ويش، آموزش هيجانات (شادى، غم، خشم و ترس)، ارائه تصاوير جهره با حالات هيجانى مختلف (شادى، غم، خشم و وترس) به به

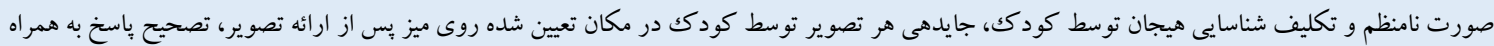

$$
\text { يسخوراند در صورت ياسخ اشتباه }
$$

آموزش هيجانات موقعيتى با استفاده از تصوير، ارائه موقعيتهاى مختلف هيجانى با تصاوير كارتونى به كودكك و شرح داستان تصوير، يرسش در مورد هيجانات

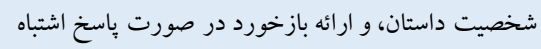

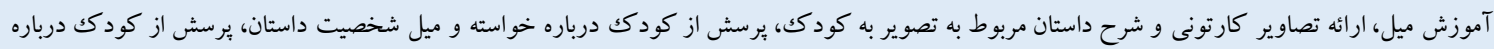

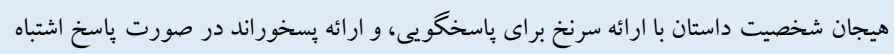

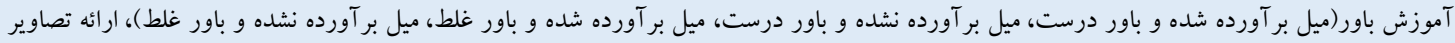

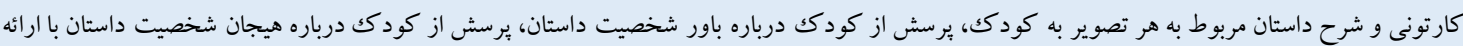

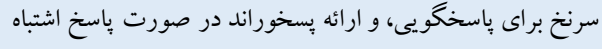

كه از آن جمله به موارد زير اشـاره مىشـود: ا. شـر كت كنند كان در اين يُزوهش به صـورت داوطلبانه وارد شـدند و وييش از شروع مطالعه از آنان

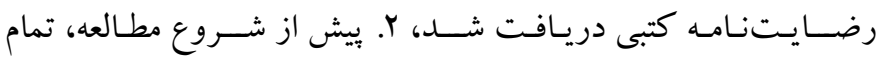

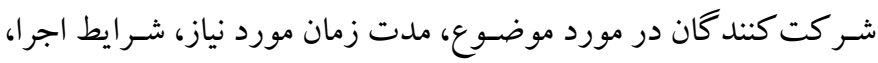
ارزيابىها، و روش اجرا مطلع شـــند، بـ با توجه به اصــل رازدارى، به

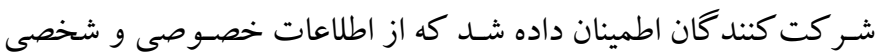
داوطلبين محافظت خو اهد شـد، F. در صـورت مشـاهده هر گونه اختلال،

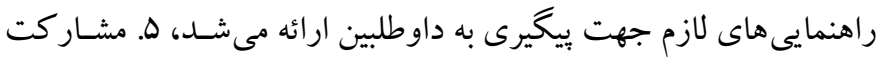

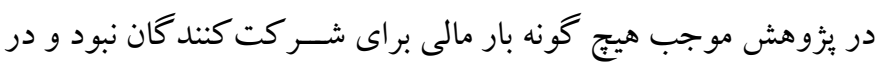

د) روش اجرا: ابتدا جلســهاى جهت شـرح فرايند آموزش نظريه ذهن

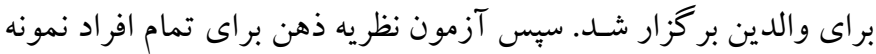

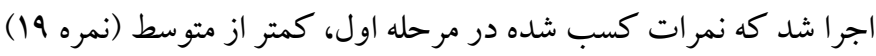

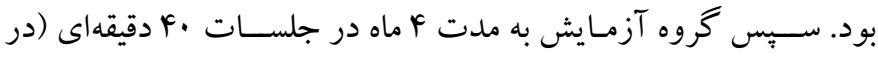
مجموع هو جلســه) آموزش دريـافـت كردنـد. بعـد از اتمـام جلســات آموزشى، آزمون نظريه ذهن براى هر دو گروه اجرا شد. جلسات در اتاق

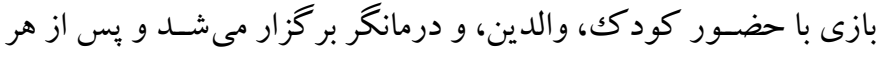

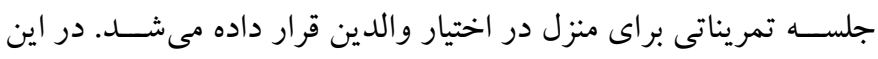

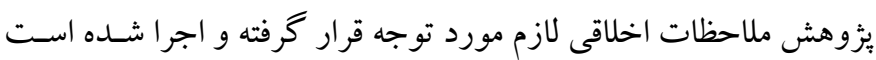


ميانگين و انحر اف اسـتاندارد نمرات بيش آزمون- بس آزمون متغيرهاى

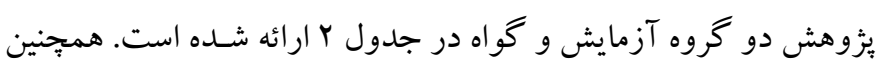

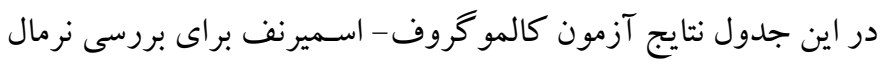

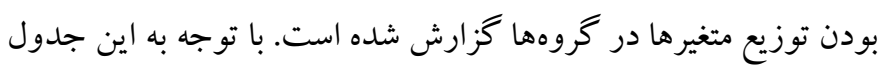

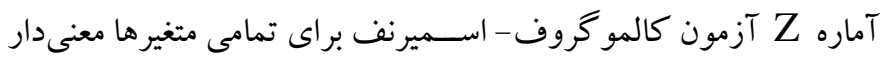

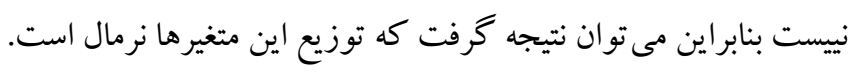

جلسات آموزش و مصاحبه از آنان يذير ايى (ميان وعده) به عمل مى آمد،

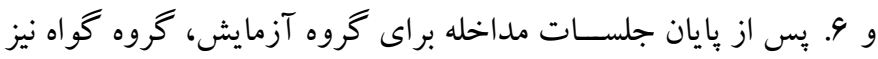
همان مداخله را دريافت كردند.

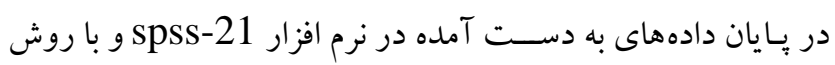

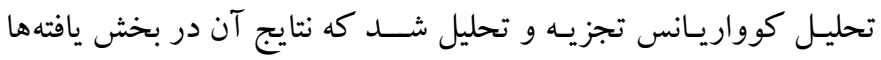
كزارش شده است.

يافتهها

جدول r: شاخصهاى توصيفى نمرات ييش آزمون- يس آزمون در دو كروه آزمايش و كواه

\begin{tabular}{|c|c|c|c|c|c|c|}
\hline $\mathbf{P}$ & K-S Z & انحراف استاندارد & ميانكين & كروه & وضعيت & متغير \\
\hline . & $\cdot / \Delta r$ & $1 / 91$ & $r / 9$ & آزمايش & \multirow{2}{*}{ يُش آزمون } & \multirow{4}{*}{ سطح اول } \\
\hline . & $\cdot / 4 q$ & $r / l r$ & $\Lambda / \& \Delta$ & كواه & & \\
\hline • & .191 & $\mathrm{r} / \Lambda$ & $\mid r / r$ & آزمايش & \multirow{2}{*}{ يس آزمون } & \\
\hline • & $\cdot / \Delta F$ & $\Delta / \Delta$. & $11 / \mathrm{V} \mid$ & كواه & & \\
\hline$\cdot / \Delta \Lambda$ & $\cdot / \Delta$ & $r / \cdot F$ & $\mathrm{r} / \mathrm{AV}$ & آزمايش & \multirow{2}{*}{ يش آزمون } & \multirow{4}{*}{ سطح دوم } \\
\hline .199 & •/ar & ケ/l. & $r / \cdot 1$ & كواه & & \\
\hline$\cdot 194$ & $\cdot / 4 q$ & $1 / F Y$ & r/IF & آزمايش & \multirow{2}{*}{ يس آزمون } & \\
\hline$\cdot / \Delta 4$ & $\cdot / \Delta \Lambda$ & $r / F F$ & $r / .9$ & كواه & & \\
\hline$\cdot / Y V$ & $\cdot / 49$ & $\cdot / 491$ & $\cdot / r \Delta$ & آزمايش & \multirow{2}{*}{ ييش آزمون } & \multirow{4}{*}{ سطح سوم } \\
\hline r &.$/ 01$ & $\cdot / \Delta 1$ & $\cdot / 41$ & كواه & & \\
\hline$\cdot / \mu F$ & .191 & $\cdot / \wedge$. & $\cdot / N V$ & آزمايش & \multirow{2}{*}{ يس آزمون } & \\
\hline$\cdot \pi v$ & .199 & $\cdot / v \cdot 1$ & $\cdot / A$. & كواه & & \\
\hline
\end{tabular}

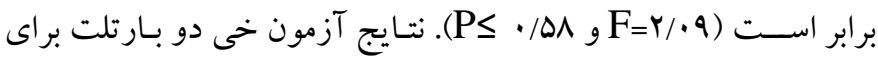

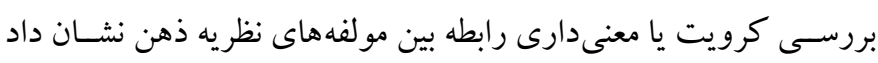

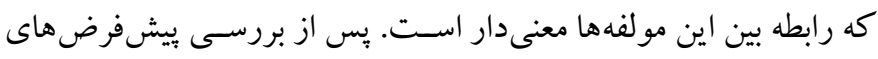

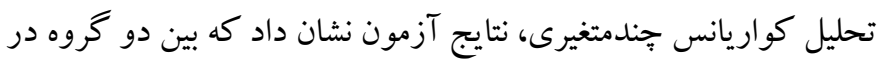
مؤلفـهـهـاى نظريسه ذهن تفـاوت معنى دارى وجود دارد (F=人/V9 و

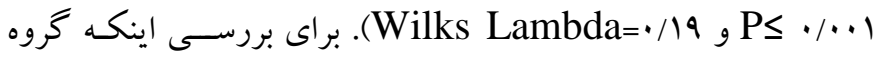
آزمايش و گ اه در كدام يكك از مولفهاى نظريه ذهن با يكديخر تفاوت

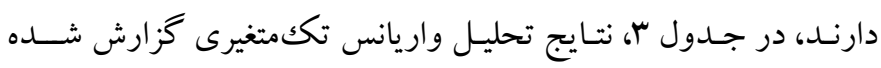

براى بررسى تأثير آموزش نظريه ذهن بر بهبود سطوح نظريه ذهن در

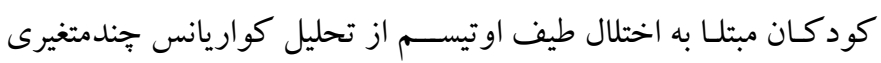

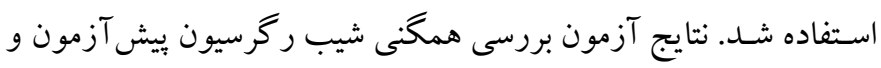

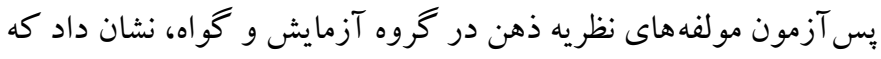

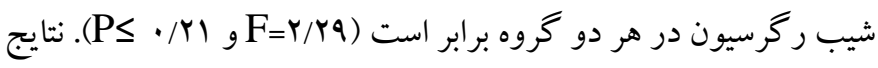
آزمون لوين براى بررسى همخنى واريانس متغيرهاى وابستهـ در خروهها دها

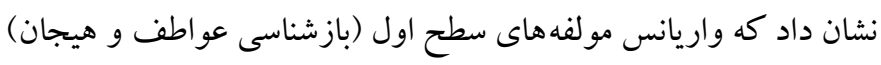

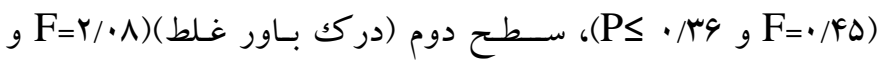

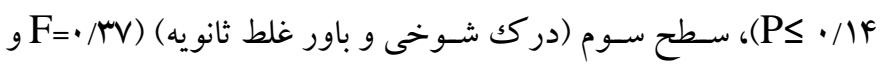

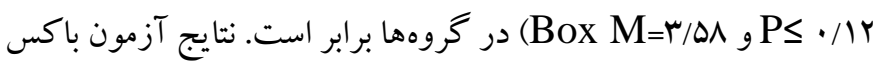

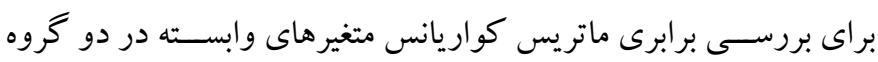


جدول r: نتايج تحليل واريانس تك متغيرى تفاوت كروه آزمايش و كواه در مؤلفههاى نظريه ذهن

\begin{tabular}{|c|c|c|c|c|c|c|c|}
\hline •/ & $\cdot / \cdot \cdot 1$ & $1 \mathrm{r} / 9 \mathrm{~V}$ & . 194 & $1 / 90$ & $\begin{array}{l}q / F r \\
F / V \Lambda\end{array}$ & كزاه & سطح اول \\
\hline$\cdot|A|$ & $\cdot / \cdot \cdot 1$ & $19 / 1 Y$ & •/19 & $r / r$ & $\begin{array}{l}9 / 4 Y \\
F / I Y\end{array}$ & $\begin{array}{l}\text { آزمايش } \\
\text { كواه }\end{array}$ & سطح دوم \\
\hline
\end{tabular}

(r) در بخشى از نتايج خود نشان دادند كه عملكرد نظريه ذهن كود كان با اختلال اوتيسم با آموزش در سطوح باور، ادراكك و ميل بهبود مئ يابد.

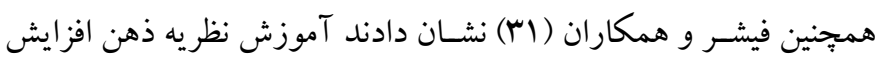
معنى دار نمرات در سطوح نظريه ذهن را در كود كان مبتلا به اختلال طيف

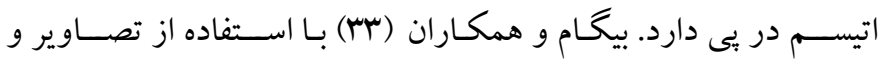
داستان كويى در ها جلسه سطوح نظريه ذهن را در افر اد با اختلال اوتيسم

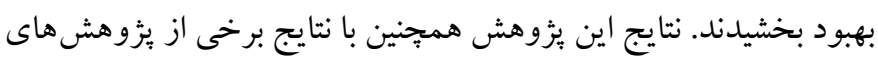
داخلى همسو است. سيفى و همكاران (ها) و اديب سر شكى و همكاران

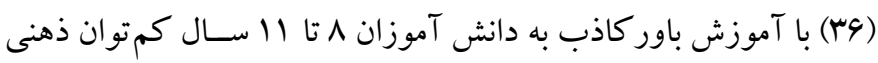
نشــان دادند كه اين آموزش موجب عملكرد بهتر در تكليف نظريه ذهن شده است. كود كــان مبــلا بـهـ اخـتلال او تيسم از نارسايى در نظريه ذهن

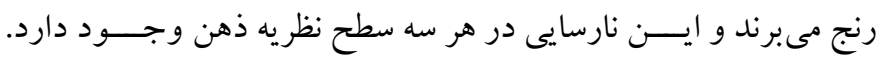

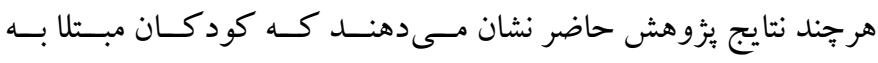

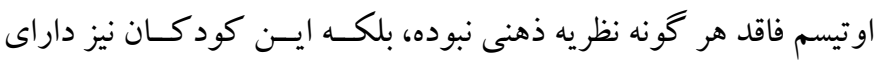
نظريه ذهن هـستند، ولى شـكل نظريـه ذهـن آنها حالتى بسيار اوليه دارد (YN)

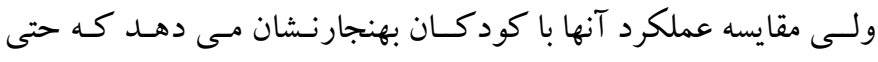

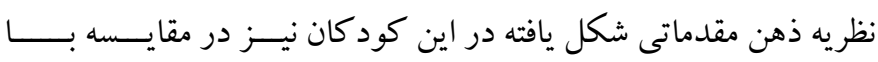

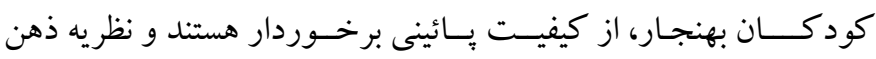
مقدماتى منسجم و كاملى نيست (rF).

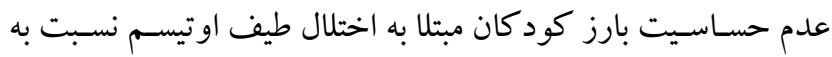

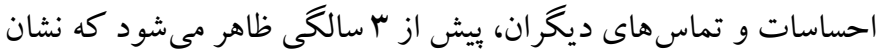
مىدهد ذهن آنها در مقطعى كه بيشـتر كود كان در برابر عقايد و اعمال

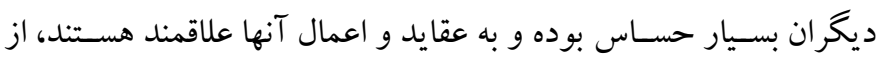

با توجه به جدول "ا، آماره F براى مولفههاى سطح اول (1 F/9V) در

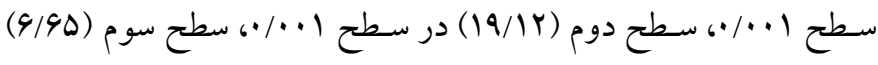
در سـطح 1 • • معنىدار اسـت. اين يافتها نشـانكر آن هسـتند كه بين

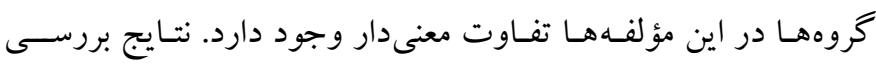

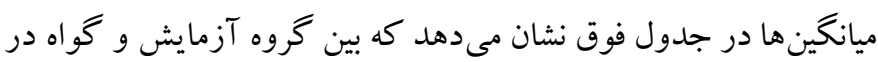
هر سـه ســـح نظريه ذهن تفاوت معنى دارى وجود دارد. با توجه به اين يـافتها مى توان كفت آموزش نظريه ذهن موجب بهبود ســـوح نظريه

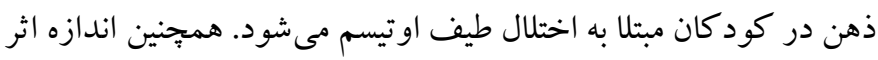
در جدول rنشـان مىدهد كه عضـويت گروهى اس درصــ از تغييرات

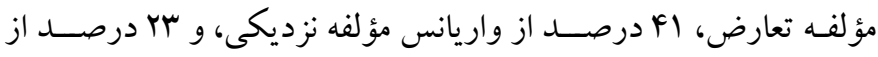
تغييرات وابستخى را تبيين مى كند.

\section{بحث و نتيجه كيرى}

اين يُزوهش با هدف بررسسى تأثير آموزش نظريه ذهن بر بهبود سـطوح

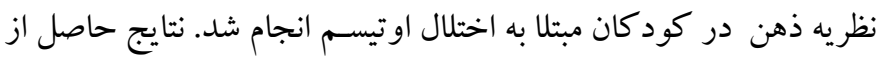

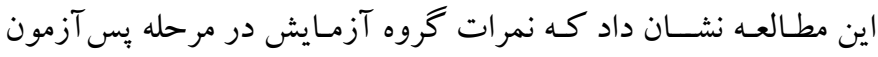
تفاوت معنى دارى نســبت به بيش آزمون وجود دارد كه ناشــى از بهبود عملكرد كودكان گروه آزمايش در تكليف نظريه ذهن است. يافتهاى يزٔوهش حاضـر نشـان داد كه آموزش نظريه ذهن، تو انايى بازشـناسى عو اطف و وانمود سـازى (سطح اول نظريه ذهن)، در كك باور غلط اوليه (سطح دوم نظريه ذهن)، و در كك باور غلط ثانويه (سطح سوم نظريه ذهن) كود كان مبتلا به اختلال اوتيسم را افزايش مى مدهد. اين نتايج

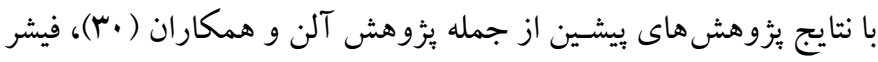
و همكاران (اس)، و گوزر و همكاران (سب) همسو است. آلن و همكاران 


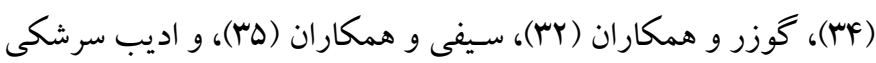

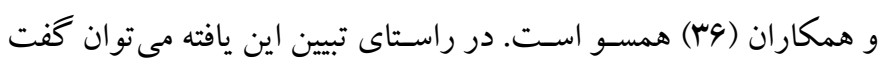

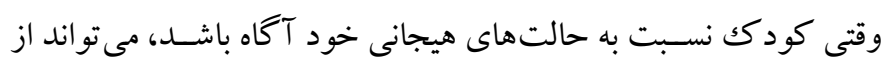

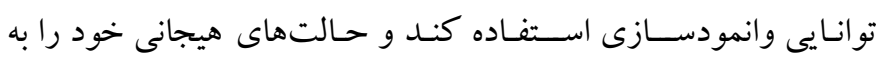

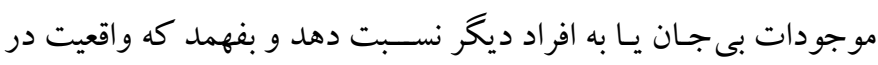

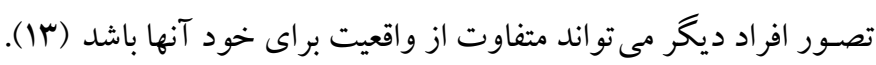

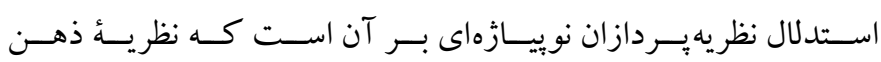

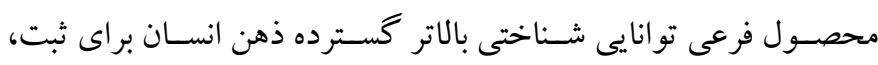

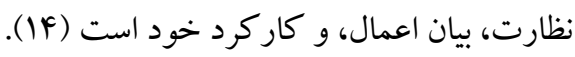
در مجموع نتايج يزوهش حاضـر نشان مىدهد كــــه اختلال اوتيسم،

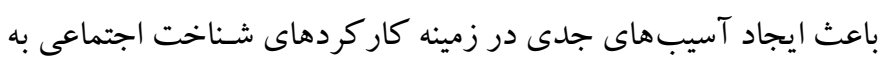

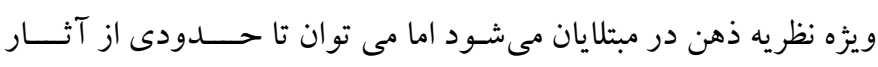

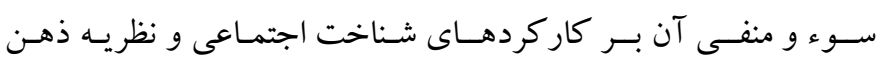

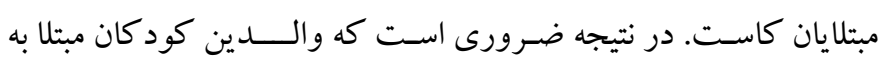

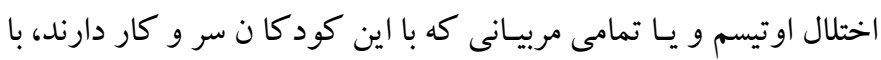

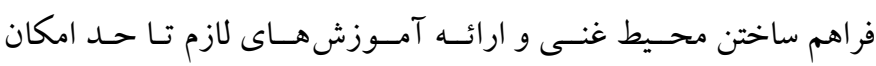
از شدت آسيببهـاى وارد بـر كـار كرد نظريسه ذهن در آنها بكاهند.

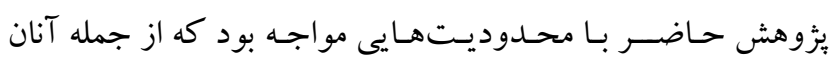

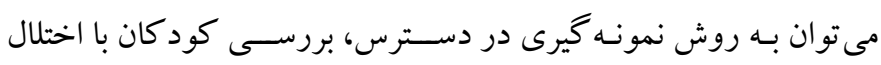

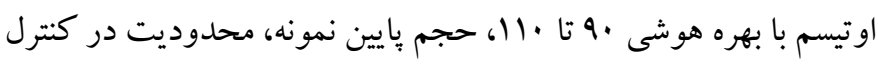

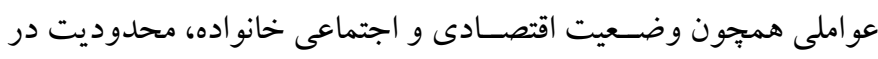
جنس (مطالعه فقط روى يسـران)، و عدم اجراى آزمون بيخيرى (به دليل

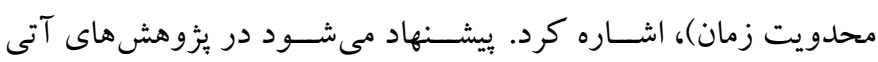

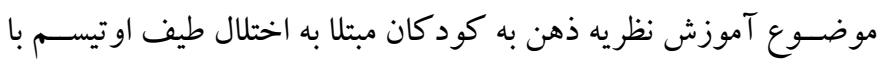

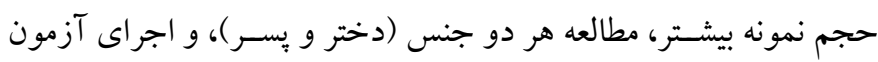

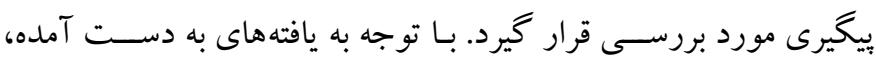

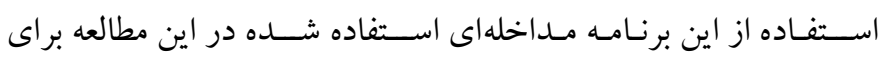

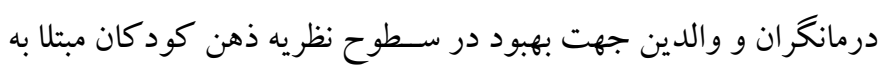
اختلال طيف اوتيسم، ييشنهاد مى شود.

تشـكر و قدردانى: اين مطالعه به صـورت مستقل انجام شـده است و حاصل

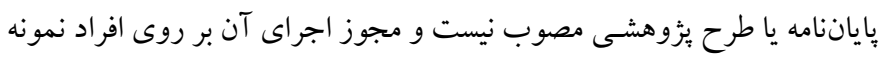
از سـوى دانشـكاه آزاد اسـلامى واحد علوم و تحقيقات تهران با شــماره مجوز
تحول بـاز مى مـانند (qY و سr). همجنين در مورد خردهمقياسها نيز بايد

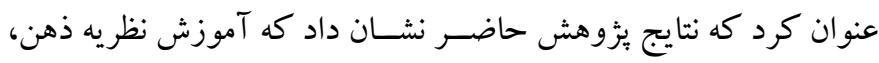
بازشـناسى عواطف و وانمودسازى را در كود كان با اختلال طيف اوتيسم

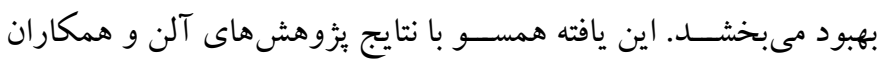

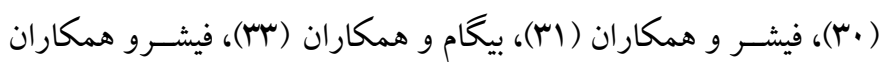

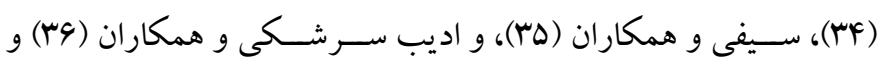

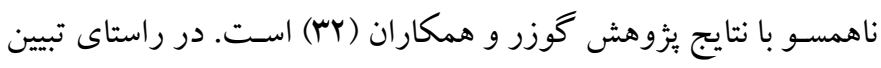

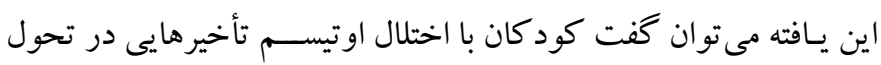

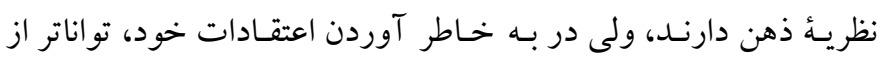

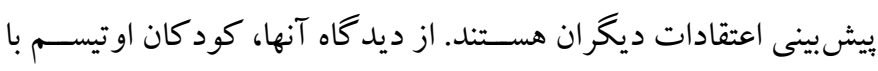

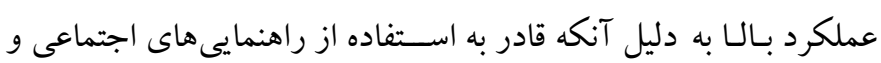

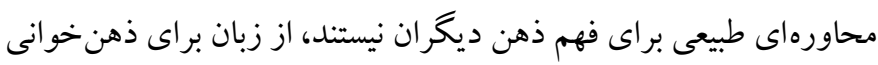

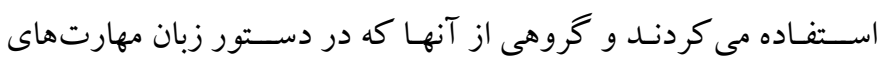

بيشترى داشتند، در تكاليف باور غلط، بهتر عمل مى كردند (·r).

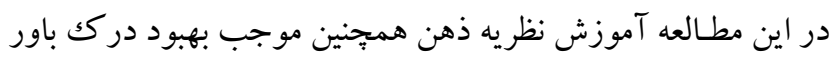

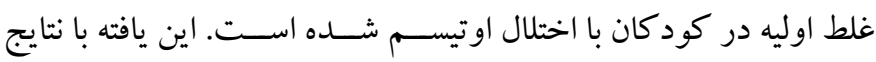

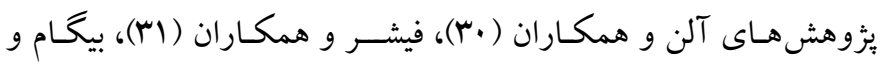

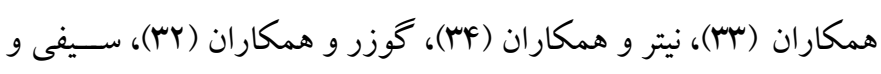

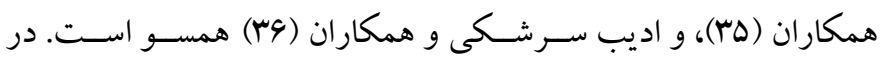

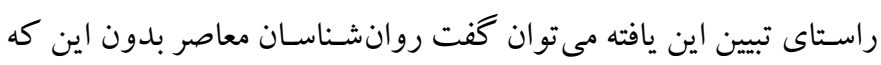
قصد ناديده گرفتن فرا يندهاى هوشى دقيق را داشته باشند، دامنه شناخت

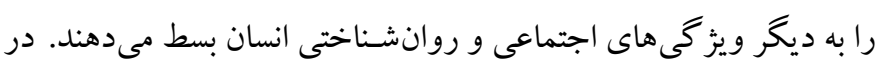

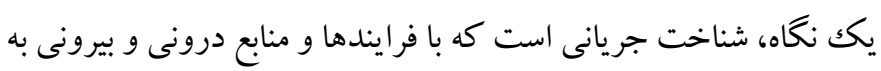

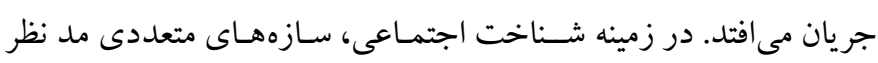

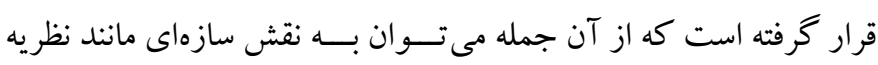

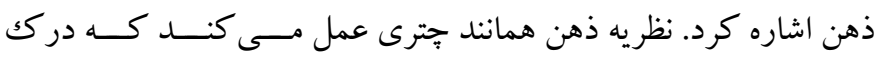

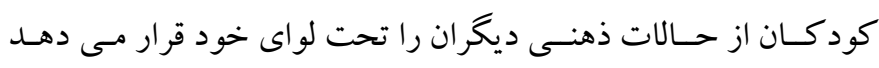

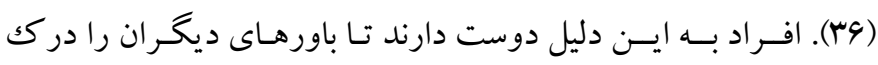

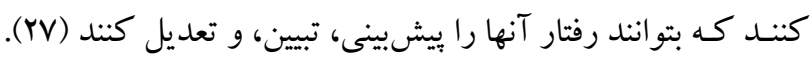
آموزش نظريه ذهن منجر به بهبود دركك باور غلط ثانويه در كود كان

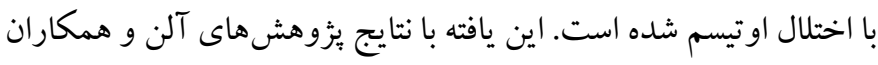

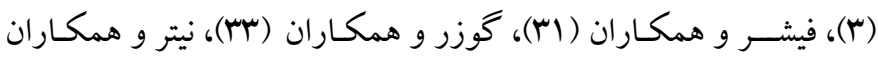


تضـاد منافع: اين يزوهش تحت حمايت مالى نهاد خاصى نبوده و تضاد منافع

ندارد.

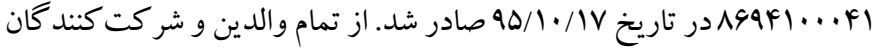

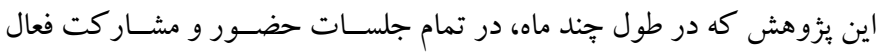
داشتند، تشكر مى كنيم. 


\section{References}

1. Ambridge, B., Bannard, C., \& Jackson, G. H. Is grammar spared in autism spectrum disorder? Data from judgments of verb argument structure overgeneralization errors. Journal of Autism and Developmental Disorders. 2015; 45(10), 3288-3296. [Link]

2. Baron-Cohen, S., Bowen D. C., Holt, R. J., Allison, C., Auyeung, B., Lombardo M. V., et al. The "Reading the Mind in the Eyes" Test: Complete Absence of Typical Sex Difference in $~ 400$ Men and Women with Autism. PLOS ONE. 2015; 10(8): e0136521. [Link]

3. Devlin H. C., Zaki J., Ong, D C., \& Gruber, J. Not as good as you think? Trait positive emotion is associated with increased self-reported empathy but decreased empathic performance. PLoS ONE. 2014; 9(10). [Link]

4. Mariano M., Pino M. C., Peretti S., Valenti M., \& Mazza M. Understanding criminal behavior: Empathic impairment in criminal offenders. Social Neuroscience. 2016; doi:10.1080/1 7470919.2016.1179670. [Link]

5. Cavallo A., Koul A, Ansuini C, Capozzi, F, Becchio C. Decoding intentions from movement kinematics. Scientific Reports. 2016; 6(1):370-385. [Link]

6. Semin GR. Communications language as an implementation device for cognition. European Journal of Social Psychology. 2000; 30(5): 545-612. [Link]

7. Boraston Z, Blakemore S, Chilvers R, Skuse D. Impaired sadness recognition is Linked to social interaction deficit in autism. Neuropsychologia. 2007; 45(7):1501-1510. [Link]

8. Huijnen CAGJ, Lexis MAS, Jansens R, de Witte LP. How to implement robots in interventions for children with autism? A co-creation study involving people with autism, parents and professionals. J Autism DevDisord. 2017;21(2): 1-18. [Link]

9. Astington J.W., Harris P.L., \& Olson D.R. Developing theories of mind. 1988; New York: Cambridge University Press. [Link]

10. Carruthers P. Language, thought and consciousness: an essay in philosophical psychology.1998; 1st ed. Cambridge: Cambridge University Press. [Link]

11. Baron Cohen S. Mind blindness: an essay on autism and theory of mind. 1995; Cambridge: MIT Press. [Link]

12. Franco F., Itakura S., Pomorska K., Abramowski A., Nikaido K., \& Dimitriou D. Can children with autism read emotions from the eyes? The eyes test revisited. Research in Developmental Disabilities - Journal. 2014; 3(5), 1015-1026. [Link]

13. Tager-Flusberg H. A psychological approach to understanding the social and language impairments in autism. Int Rev Psychiatry. 1999; 11(4): 325-34. [Link]

14. Demetriou A., Mouyi A., \& Spanoudis G. The development of mental processing. Journal of Autism \& developmental Disorder. 2010; 21, 254-268. [Link]

15. Moore S. Asperger Syndrome and the Elementary School Experience. Shawnee Mission Kansas. Publishers cataloging-in Publication. 2002. (Provided by quality books, Inc). [Link]

16. Xin JF, Sutman FX. Smart board in teaching Social Stories to students with autism. Teaching Exceptional Children. 2011; 43(4): 18-24. [Link]

17. Pino M C., Tempesta D., Catalucci A., Anselmi M., Nigri A., Iaria G., et al. Altered Cortico-Limbic Functional Connectivity During an Empathy Task in subjects with Post-Traumatic Stress Disorder. Journal Psychopathological Behaviour Assessment. 2016; doi:10.1007/s10862-016-9538-x. [Link]

18. American Psychiatric Association. Diagnostic and Statistical Manual of Mental Disorders: DSM-V, 5th edn. Arlington,VA: American Psychiatric Publishing. 2013. [Link]

19. Folstein SE, Rosen-Sheidley B. Genetics of autism: complex etiology for a heterogeneous disorder. Nat Rev Genet. 2001; 2(12): 943-55. [Link]

20. Conti D, Di Nuovo S, Buono S, Trubia G Di Nuovo A. Use of robotics to stimulate imitation in children with Autism Spectrum Disorder: A pilot study in a clinical setting. 2015; 14(1):176-191. [Link]

21. Volkmar FR, Pauls D. Autism. Lancet. 2003; 362(9390): 1133-41. [Link]

22. Baron-Cohen S, Wheelwright S. The empathy quotient: an investigation of adults with Asperger syndrome or high functioning autism, and normal sex differences. J Autism DevDisord. 2004; 34(2): 16375. [Link]

23. Dunn W, Myles BS, Orr S. Sensory processing issues associated with Asperger syndrome: a preliminary investigation. American Journal of Occupational Therapy. 2002; 56(1):97-102. [Link]

24. Valle, A., Massaro, D., Castelli, I., and Marchetti, A. Theory of mind development in adolescence and early adulthood: the growing complexity of recursive thinking ability. Euro. J. Psychol. 2015; 11, 112-124. doi: 10.5964/ejop.v11i1.829 [Link] 
25. Baron-Cohen S. The extreme male brain theory of autism. Trends in Cognitive Sciences. 2002; 6(6):24854. [Link]

26. Robins B, Dautenhahn K. Tactile Interactions with a Humanoid Robot: Novel Play Scenario Implementations with Children with Autism. International Journal of Social Robotics. 2014; 11(1):160-175. [Link]

27. Baron-Cohen S, Golan O, Ashwin E. Can emotion recognition ne taught to children with autism spectrum conditions? Philosophical transactions of the Royal Society, Biological Sciences. 2009; 364(1535): 35673574. [Link]

28. Baron-Cohen S, Leslie AM, Frith U. Does the autistic child have a "theory of mind"? Cognition. 1985; 21(1): 37-46. [Link]

29. Klin A, Jones W, Schultz R, Volkmar F. The enactive mind, or from actions to cognition: lessons from autism. Philosophical Transactions B. 2003; 358(1430):345-60. [Link]

30. Allen B, Timmer S, Urquiza A. Parent-Child Interaction Therapy for sexual concerns of maltreated children: A preliminary investigation. Child Abuse and Neglect. 2016; 56(3): 80-88. [Link]

31. Fisher N, Happé F, Dunn J. The relationship between vocabulary, grammar, and false belief task performance in children with autistic spectrum disorders and children with moderate learning difficulties. J Child Psychol Psychiatry. 2005;46(4):409-19. 17. [Link]
32. Gevers C, Clifford P, Mager M, Boer F. Brief report: a theory-of-mind-based social cognition training program for school-aged children with pervasive developmental disorders: an open study of its effectiveness. J Autism DevDisord.2006; 36(4):56771. [Link]

33. Begum M, Serna RW, Yanco HA. Are robots ready to deliver autism interventions? A comprehensive review. Int J Soc Robot. 2016; 8(4): 157-181. [Link]

34. Nieter L, Thornberry T, Brestan-Knight E. The effectiveness of group parent-child interaction therapy with community families. Journal of Child and Family Studies. 2013; 22(4): 490-501. [Link]

35. Seyfi R, Salehi Omran E, Panahandeh Vanesfaghi K. Effectiveness theory of mind on the promotion of the theory of mind of children with high-functioning autism. Journal of Empowering Children, Vol. 6, No. 2 (14), Summer 2015, 1-8. [Link]

36. AdibSareshki, Narges; Pourmohammad Reza Tajrishi, Masoomeh; AbdollahZadeh Rafi, Mehdi. The Effect of Teaching Theory of Mind on Improving Adaptive Behavior of Mentally Retarded Students. Research project of University of Social Welfare and Rehabilitation Sciences. 2010. [Persian] [Link]

37. Ghamarani O, Alborz E. The validity and reliability test" theory of mind in a group of students with mental retardation and normal city. Journal of Psychology. 2006; 10: 199-181. [Persian] [Link]

38. Hale, C.M., \& Tager-Flusberg, H. (2003). The influence of language on theory of mind: a train study. Development science, 3, 346-359. [Link] 